\title{
DEVELOPING MOBILE LEARNING AS ECOLOGY PRACTICAL TOOL USING THREE-LAYER OBSERVATION FRAMEWORK
}

\author{
Rizki Agung Sambodo ${ }^{1 *}$, Baskoro Adi Prayitno ${ }^{1}$, Puguh Karyanto ${ }^{1}$, and Eka Sulistyowati ${ }^{2}$ \\ ${ }^{1}$ Department of Biology Education, Universitas Sebelas Maret, Solo, Central Java, Indonesia \\ ${ }^{2}$ Department of Biology Education, Universitas Islam Negeri Sunan Kalijaga, \\ Yogyakarta, Indonesia \\ *Corresponding e-mail: gebangtengah@gmail.com
}

\begin{abstract}
Developing practical tool in ecology that addresses the challenge of transferring ecological concept systematically has becoming essential factor in achieving better understanding of the teaching process. Three-layer Observation Framework (TlOF) is one of the best methods that can be adopted in designing practical work in ecology since its power in providing a step-by-step concept reconstruction. This research aimed to develop a sample of practical work in ecological teaching and learning based on the TlOF. This research followed the ADDIE method in developing the product with some modifications. The research focus was set to gain product's appropriateness from validators and users. The developed product was tested in Biology Education Department at the State Islamic University of Sunan Kalijaga, Yogyakarta in order to collect responses for further product improvement. The results of the appropriateness test from three validators showed that the developed product is "very good" with an average score of 81.8. During the performed preliminary test by users, as high as 82.5 was achieved. It means that the developed product gained a good perception from the respondents. According to the results, TlOF-based mobile learning practical tool is potential to become an alternative media in improving practical work in term of encompassing ecological concepts.
\end{abstract}

Keywords: Ecological concepts, mobile learning, three-layer observation framework

(C) 2018 Department of Biology Education, FTTE, University of Muhammadiyah Malang, Indonesia

\section{INTRODUCTION}

The rapid changes in sciences, environment, technology, and society has caused significant changes in methods and strategies in learning science. Today, learning science is not only related to the mastering of declarativeknowledge but also related to procedural knowledge. In learning science, when students learn to memorize, there is a possibility that they will fail to compete in the global era (Bybee, 2010). Therefore, an ideal science learning is not only aimed at answering questions of "what" but also "why" and "how". Besides, to be able to answer the questions of "why" and "how", the student needs to be involved in the designed teaching and learning processes.

As a science, biology must deal with procedural rather than declarative knowledge (Osuafor \& Amaefuna, 2016). The practical exercise is an appropriate method in biological teaching and learning (Wulandari, Kurnia, \& Sunarya, 2013). Practical exercises enable students to be involved in activities that lead to the improvement of their concepts in practical and theoretical knowledge as well. Practical exercise helps students to be trained in term of their scientific skills including formulating research questions, making an observation, dealing with data uncertainties, analyzing and interpreting data, and composing data-based argumentations (Hung, Hwang, Lin, $\mathrm{Wu}, \& \mathrm{Su}$, 2013). It also plays importantly in building scientific skill process and broadening their scientific perspectives (Y. M. Huang, Lin, \& Cheng, 2010; Wulandari et al., 2013). Moreover, researches deal with the lower level of education (for example high in school) show that practical exercises bring positive correlation towards student scientific perspective (Hayat, Anggraeni, $\&$ Redjeki, 2011). Hence, it is arguable that practical exercises could be given along with theory to enhance both, practical skill and theoretical concepts as well.

Contextual teaching and learning are essential in studying ecology. Indeed, ecology is 
about to study the interaction between the organism and the environment. The objects of ecology cover all level of stratification including species, community, population, interaction pattern, material and energy flow, and climate change (Ajizatunnisa, Wahyuni, Waluyo, \& Miharja, 2018; Lewinsohn et al., 2014). In general, ecology deals with macroscopic objects and, considered as multidisciplinary. Effective ecological teaching must to involve real nature object and employ an active data gathering in the field. Therefore student participation and collaboration with others is critical during the teaching and learning process to build a more cooperative process (Schaal, Matt, \& Grübmeyer, 2012).

Conducting contextual teaching and learning in ecology may bring great consequences for both the teacher and student in helping the student to focus on the given tasks and instruction. The unpredictability of unnecessary information may exacerbate all instructions, primarily related to how student's brain is used in storing and processing information and instruction.

The human brain works similarly to the computer's memory. Complex information may lead to overworked working memory (Hung et al., 2013). Working memory will be equal with cognitive system consumed by human's brain, in which the information is stored and process (Shipstead, Lindsey, Marshall, \& Engle, 2014). In these disturbances, the student will lose their ability to focus on the teacher's instruction as storing capacity and duration of working memory are limited (Kirschner, Sweller, \& Clark, 2006; Tulbure \& Siberescu, 2013). An overload working memory will interfere with a process of how information is processed in the brain due to competition between important information with another un-useful data. This may cause a failure in accomplishing the instruction during practical exercises.

Working memory will be more effective when information is directly connected with the given instruction (Hung et al, 2013). Cognitive Load Theory (CLT) states that instructional guides ease the task of working memory (Kirschner et al., 2006). The instructional guide serves as a tool for ensuring effective data processing. In this case, instructions help to guide and structure the available information which in turn will comprehensively improving learning interdependence and facilitating knowledge transfer (Hung et al., 2013; Husamah, 2015).

Common practical exercise in ecology as in UIN Sunan Kalijaga is performed in a conventional method using a functional module. The module is applied with insufficient instruction, making this tool is unable to ensure a systematic knowledge reconstruction. The conducted observation reflects the failures of the applied module in facilitating ecological concept transfer. A survey upon 54 student participant's show that half of the students fail to understand the stated concept in the module. At $67 \%$ of the student, participants found difficulties in solving some mathematical formula. At $71 \%$ of students are unable to use the instruction without lecturer's explanation

The result as mentioned above of observation tells the importance of developing practical exercise by incorporating digital technology in the blended learning concept (Husamah, 2015). The smartphone is an appropriate technology that is potential to be engaged in facilitating selflearning processes as its high portability, flexibility, and connectivity. These power may support indoor and outdoor teaching and learning process in ecology (Chen, Kao, \& Sheu, 2003; Y. Huang, Liao, Huang, \& Chen, 2014; Sung, Chang, \& Liu, 2015).

Common mobile teaching and learning tools considered ineffective since it only displays learning materials and feedbacks in the form of multiple - choice questions. This cause students to fail in reconstructing their inquiry skill since the available media is dominated by text. A solution to overcome this problem is by integrating mobile learning using a three-layer observation framework (TlOF) (Hung et al., 2013).

TlOF provide important stages namely: 1) guided observation, 2) Independent observation, and 3) extended inquiry (Hung, Lin, \& Hwang, 2010). The three-layer observation framework provides not only feedback in the form of multiple-choice questions but also worksheets. Students' working memory is gradually guided, which in turn making students to focus on completing the instruction (Hung et al., 2013). The abovementioned challenge must be addressed by the teacher to ensure the effectivity of practical exercise in ecology. This research aims to develop mobile learning tools for teaching and learning in ecology based on the TlOF. 


\section{METHOD}

This study employs the R\&D design in developing mobile learning functional exercise module based on a three-layer observation framework. ADDIE steps (Branch, 2009) was followed with few modifications. Evaluation stage in the ADDIE was modified by conducting this step at every stage of this research. The implementation step in the ADDIE was changed by put this critical step in the large-scale pilot and effectivity test. Small-scale implementation was used altering the effectivity test in order to collect the feedback for product improvement. The small-scale test was carried out towards university student of UIN Sunan Kalijaga Yogyakarta.

The quality of the product was checked using questionnaires adapted from Crozat, $\mathrm{Hu}, \&$ Trigano (1999) and Noviar (2016). The chosen aspects are curriculum, content, implementation, evaluation, language, technical quality, usability, visual media elements, and compatibility. The student was asked to express their interest in the media and their feasibility of using the product. The information gathered during the conducted data collection was analyzed descriptively by referring Formula 1 (Arikunto, 2013). The result of the analysis is presented in Table 1.

$$
P=\frac{\sum x}{\sum x i} \times 100 \%
$$

$P \quad:$ Percentage

$\sum x$ : Total number of score per item

$\sum x i$ : Total number of ideal score per item

Table 1. Validation criteria and decision making

\begin{tabular}{ccc}
\hline $\begin{array}{c}\text { Percentage } \\
(\%)\end{array}$ & $\begin{array}{c}\text { Validation } \\
\text { Level }\end{array}$ & Explanation \\
\hline $81-100$ & Very Good & No need revision \\
$61-80$ & Good & Partial revision \\
$41-60$ & Fair & Partial revision \\
$21-40$ & Bad & Total revision \\
$<20$ & Very Bad & Total revision \\
\hline
\end{tabular}

\section{RESULTS AND DISCUSSION}

\section{Product's description and specification}

The sample of TlOF-based mobile learning product that was developed in this research entitled the "Gastropoda Air Tawar" or Freshwater Gastropoda. The application is saved into a master installer file with the extension *.APK (application package). The installer application master is used to install the application on the student's Android-based mobile phone.

The application consists of several submenus namely Course Contents (materials), Research, Evaluation, Discussion, and Information. Each sub-menu has a specific function to facilitate student during a practical exercise. The sub-menu of 'Material' contains the explanation of freshwater gastropods and the roles of gastropod in the environment. The submenu of 'Research' contains the steps of ecological fieldwork as well as the procedure of data collection methods.

Sub-menu of 'Discussion' provides an online communication tool for students via the internetbased network. Students can send messages and comments using the tool. The sub-menu of 'Evaluation' helps the student to evaluate their understanding of theoretical content together with their practical skill and competencies. In the sub-menu of 'Info', a brief explanation of the application and contact information of the admin that create an application is provided.

The sample of the TlOF-based product is highly portable and flexible and, can be run online and offline using smartphones. This application is also downloadable from app-store. The front cover of the product can be displayed in Figure 1 and Figure 2.

\section{Steps of developing the TIOF-based mobile learning media for practical exercise in ecology}

\section{Need analysis}

The results of this preliminary research show the ability of the developed Android-based threelayer observation framework module for practical exercise in ecology in facilitating concept mastering. This is because of some comparative value bear by this product. The ability of the product in supporting fast cognitive recalling is one of the points. The three-layer ensures systematic information arrangement in the brain, making the stored information and data are accessible to recalled (Hung et al., 2013).

Narrow observation towards the willingness to bring references reveals facts that $89 \%$ of the students did not bring any reference, $74 \%$ students did not bring identification books, while $11 \%$ students did not bring practical worksheets during fieldwork activities. A percentage of $84 \%$ of students preferred to bring soft materials or files rather than the hard one. The developed TlOF-based mobile learning media can address 
the challenges of this preference. Ecological references can be stored in the sub-menu unlimitedly, providing as a source of reference in discussing the data resulted during a practical exercise. Despite the facts mentioned above, almost all student have good access using their smartphone during the field work. This fact implies that student is familiar with smartphone representing the data reported by UNESCO telling many mobile devices users in Indonesia that reaches $91.7 \%$ of its total population (Isaacs, 2012).

Regarding the use of operating systems, the students reported to used android, iOs, blackberry, and java. The Android operating system shows the highest percentage of users (88\%). Blackberry and iPhone Os (iOs) users were the second ranks, with the percentage of users at $5 \%$ each. Only $2 \%$ of the user used a Java operating system. The detail data are presented in Figure 3.

The above data of students' mobile device operating system is relevant with the data retrieved from http://gs.statcounter.com that tells that the Android is the most occupied operating system in Indonesia with a percentage of $76.3 \%$. This may be due to its lower price and accessibility and its capacity to support internet connectivity (Singh \& Jain, 2014). Observation also found that $48 \%$ of students possess difficulties in understanding the provided worksheet. Student fails to follow the incomplete direction and can not sense the figure presented in the worksheet. This case had lead student into misperception towards the field practical procedure. For example, during the titration procedure 4 of 7 groups fail to follow the correct procedure of measuring the dissolved oxygen. It can be concluded that assists still needed to complement the worksheet. This is in line with Hung's opinion that the challenge of the worksheet of practical exercise is in its lack of expert guides and appropriate field tools and reference (Hung et al., 2010). Therefore an efficient, practical exercise guide is needed to help students in conducting their fieldwork. In ecology, this case is also important to be solved as teaching and learning in ecology stated specific learning outcomes. It is not purely cognitive but also builds the environmental, behavioral intention as well (Lewinsohn et al., 2014).

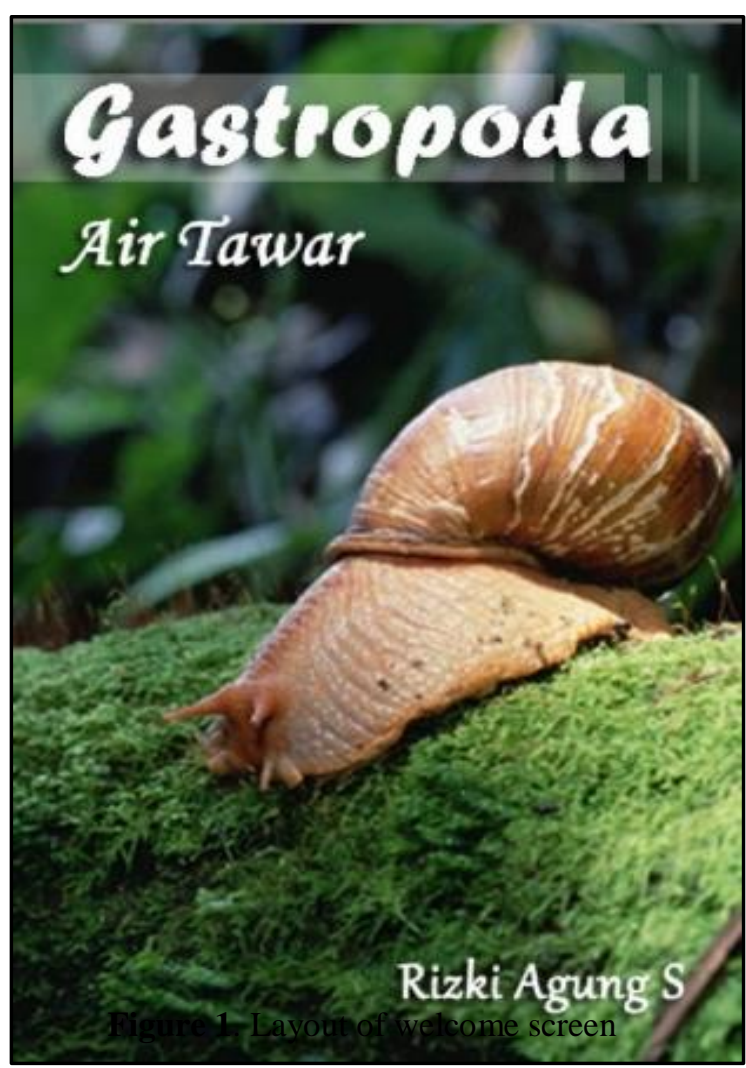

Figure 1. Layout of cover/welcome screen

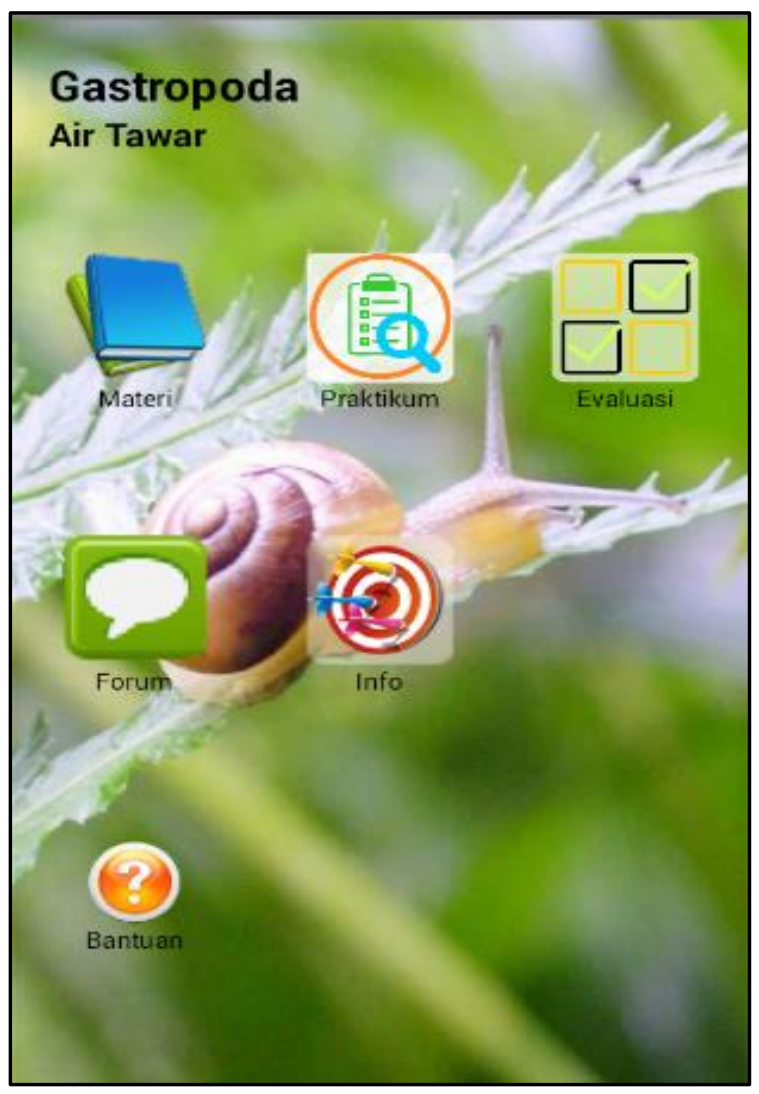

Figure 2. Layout of main menu 
Sambodo et al. / JPBI (Jurnal Pendidikan Biologi Indonesia) / 4 (3) pp. 225-234

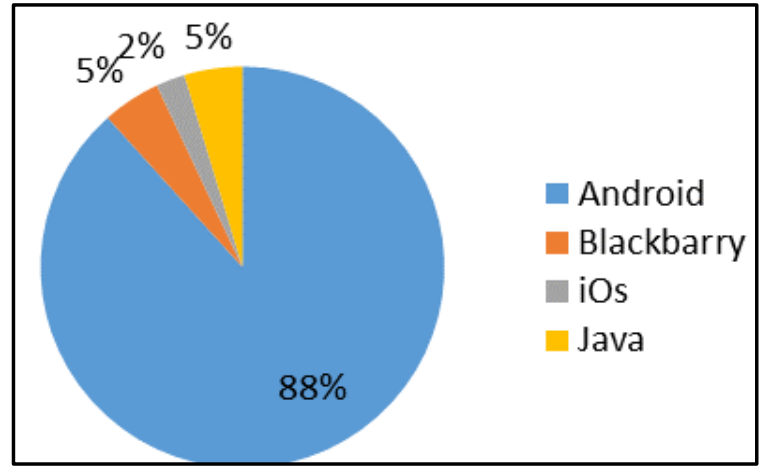

Figure 3. Percentage of the OS users Design

The next step in the ADDIE is about how to design the product. In this step, the researchers developed a prototype of mobile learning application and design. Interfaces, material frameworks, and application of the frameworks. The interface application refers to the seven principles of mobile learning design namely customizing the display into a small screen, arranging ecological content, making the system is more accessible to operate with one hand, simplifying the color elements, making content relevant to the need and ensuring the system to be easily updated on a regular basis (Noviar, 2016). The TlOF accommodates this seven principle. This research employs the TlOF as the basic method in developing the product. The TlOF procedures are illustrated in Figure 4.

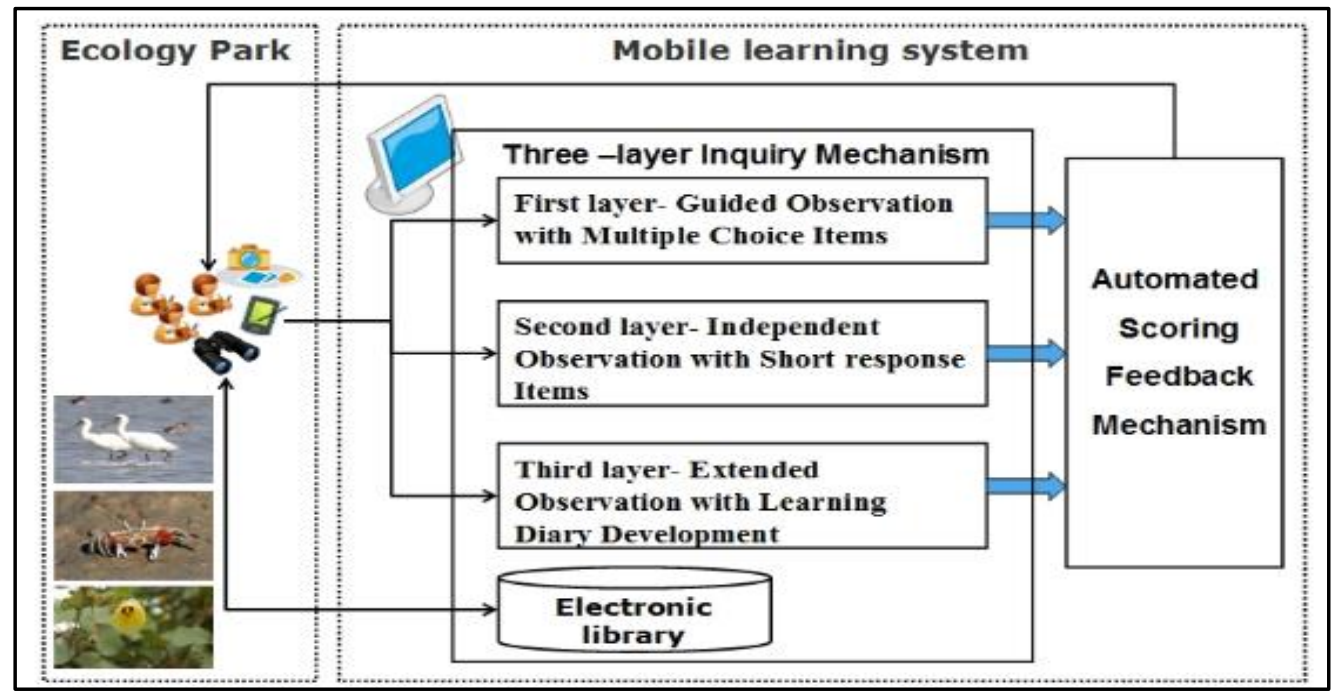

Figure 4. Three-layer observation learning

The framework used in the practicum menus refers to three-layer observation framework Hung et al., (2013) hat consists of 1) guiding students with multiple choices, 2) guiding students with short questions, and 3) giving back answers directly in the application. Complete steps of three-layer observation learning are illustrated in the above Figure 4. The result of the design stage was an application prototype that was continued at the developing stage in the ADDIE.

The first step of guided observation with multiple choice questions (Figure 5a) is implemented by giving the students multiple choice questions in order to check students' factual knowledge. The questions consist of 10 questions taken randomly from the database. The database provides 20 variations to ensure that each student will get the questions in different order and form. The answer key will directly accompany each question that answered by the students. The key is displayed immediately to help the student to remember the answers spontaneously. At the end of the multiple choice session, students are scored and reviewed in term of their work in answering the answer (Figure $5 b)$. The score is used as a reference for the next step in the second phase. Only students who pass the passing grade (above 60) are allowed to continue the step. Students scored 60 or less should repeat answering the multiple choice questions.

In the second stage, the students are encouraged to perform self-observation by filling out a short spreadsheet on the application. The worksheet consists of location, DO water, $\mathrm{pH}$ of water, temperature, current velocity and sampling of species (Figure 6a). The students can choose the worksheet that will be answered first. The view of the temperature worksheet is shown in Figure $6 b$. 


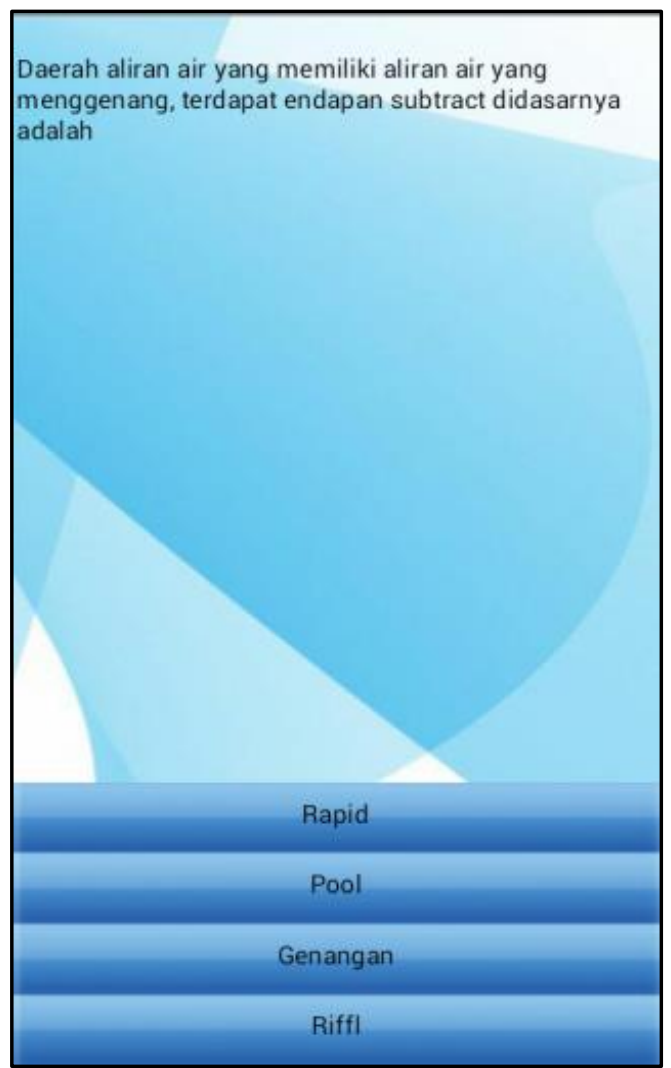

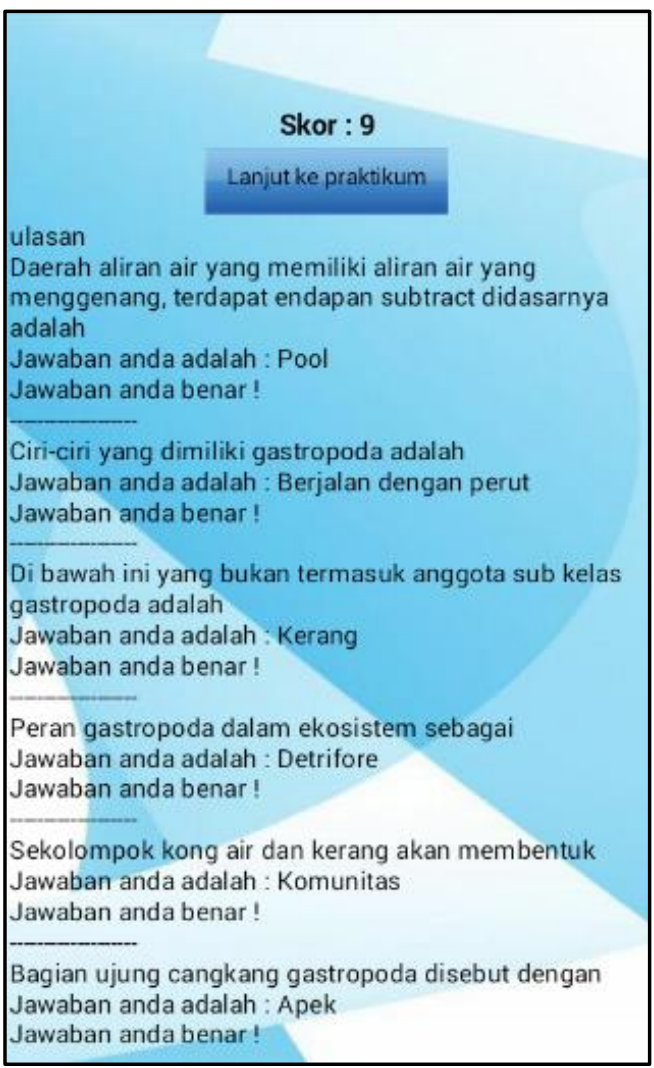

Figure 5. (a) Exercise screenshoot, (b) Discussion screenshoot
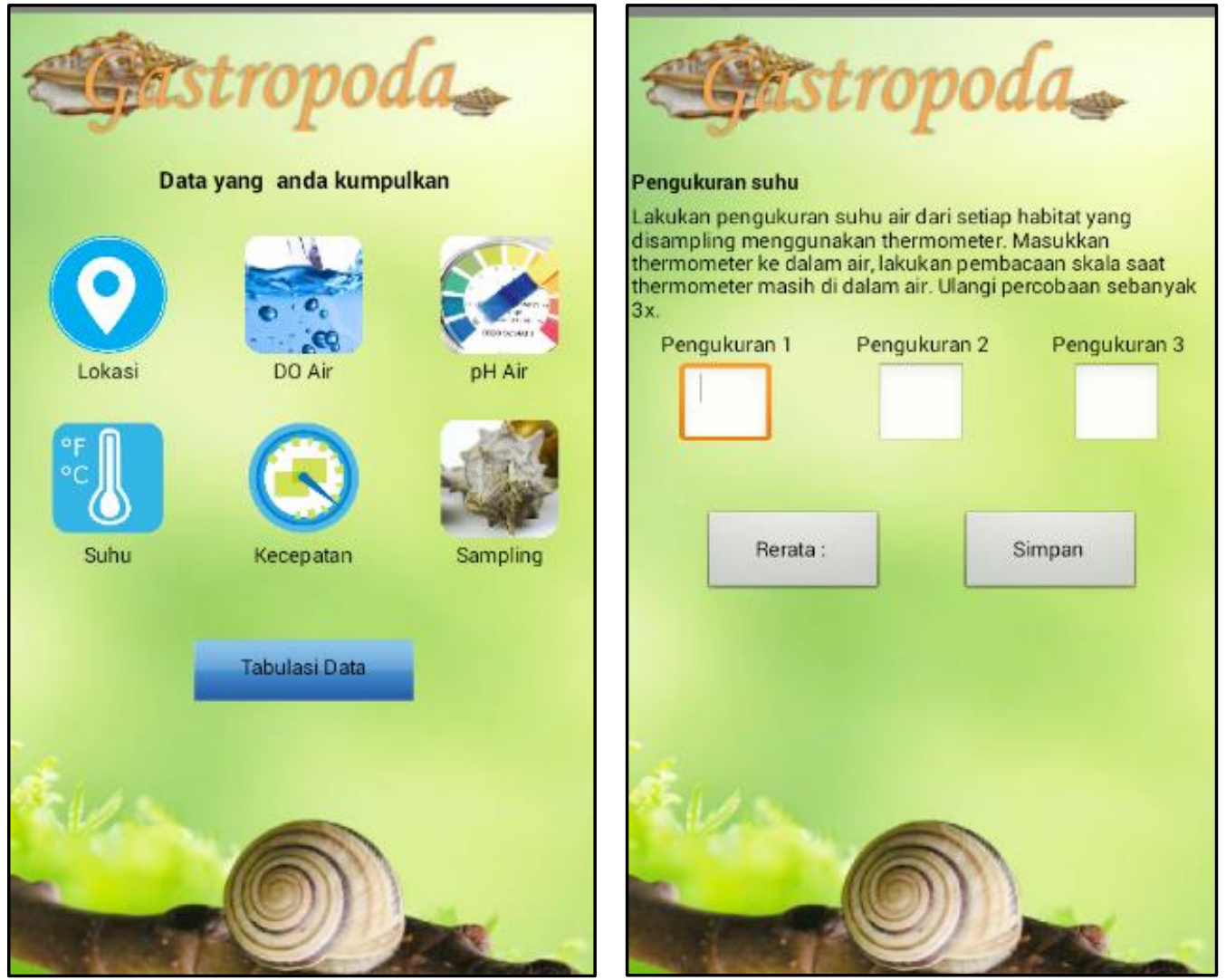

Figure 6. (a) The layout of practicum menu before getting a revision, (b) layout of temperature worksheet 
Students explore the observation data more deeply at the third stage. The data collected in each worksheet is collected in a screen so that students can see in advance the data that have not yet been collected (Figure 7). If the data are incomplete or do not reflect the normal trend of measurement, the students can repeat inputting data to the worksheets. The purpose of editing this data is to allow the students to reflect their work.

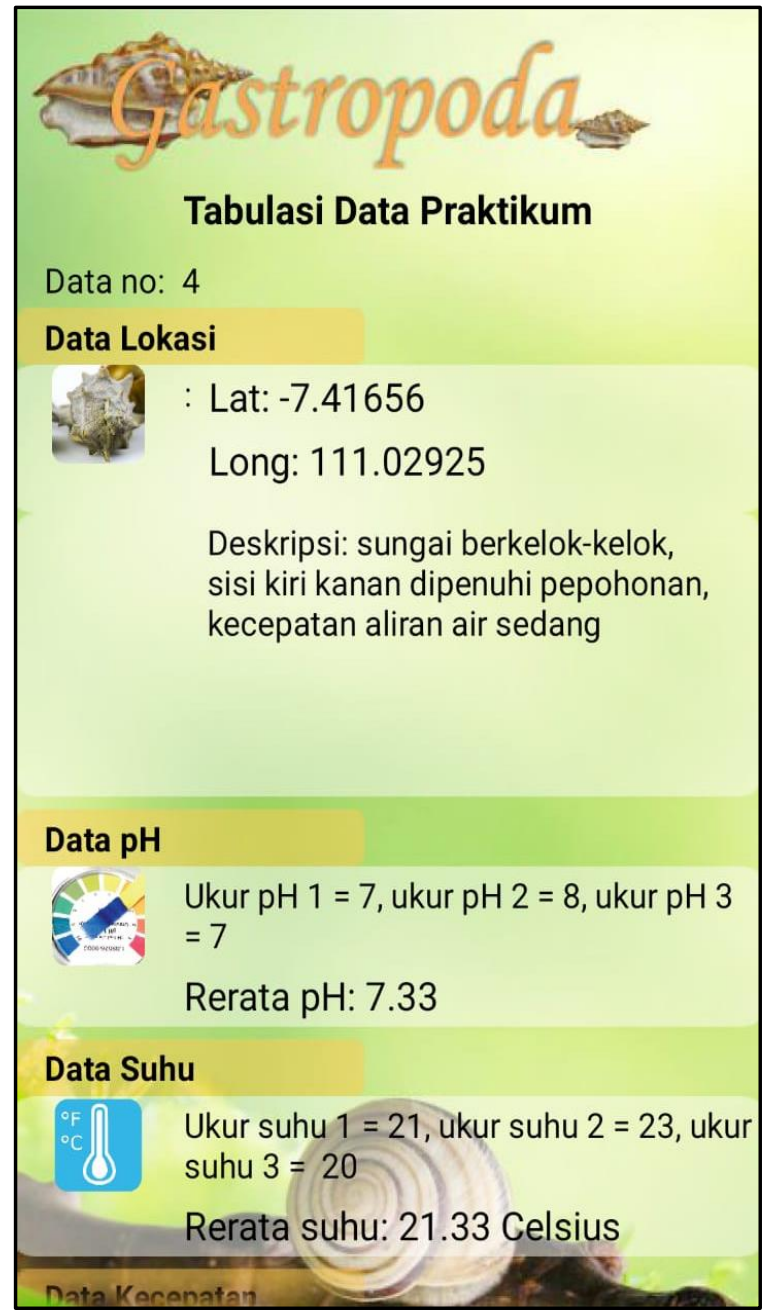

Figure 7. Layout of display data

The develop stage aims for assessing the quality of the product based on the expert's judgment. The experts will examine the content and the developed media. The assessment results of all reviewers and peer reviewers are presented in the below Table 2 .

Examiner was employed to assess aspects such as curriculum, material, implementation, evaluation, language, technical quality, usability, visual media elements, and compatibility. The tlof-based product gained a total score of 98.20 with an ideal percentage of $81.8 \%$. The $\mathrm{X}$ score
(98.20) that falls in the range of $X>72$ which is categorized as very good (VG). Similarly, the ideal percentage $(81.8 \%)$ which is categorized as very good (VG).

Table 2. Product quality

\begin{tabular}{clcc}
\hline No & \multicolumn{1}{c}{ Aspect } & $\begin{array}{c}\text { Percentage } \\
(\boldsymbol{\%})\end{array}$ & Quality \\
\hline 1 & Curriculum & 84.0 & VG \\
2 & Material & 80.8 & VG \\
& Presentations & 82.0 & VG \\
3 & Accomplishment & 78.0 & $\mathrm{G}$ \\
4 & Evaluation & 80.0 & $\mathrm{G}$ \\
5 & Linguistic & 85.0 & $\mathrm{VG}$ \\
6 & Technical quality & 72.0 & $\mathrm{G}$ \\
7 & Usability & 88.0 & $\mathrm{VG}$ \\
8 & Elemen visual & 82.0 & $\mathrm{VG}$ \\
9 & Compatibility & 81.8 & $\mathrm{VG}$ \\
\hline \multicolumn{3}{c}{ Average } \\
\hline \multicolumn{3}{c}{ Explanation: VG-Very good, G-Good }
\end{tabular}

The visual aspect gets the highest score, $88 \%$. The visual element aspect measures the use of visual elements such as text, text alignment with the background, and illustrations (pictures and videos). The ideal score shows that the product displays visual elements that are categorized according to text size, font selection, proportional text color, text and suitable background, and resolution. Meanwhile, the usability aspect of the product scored $72 \%$, lower than other aspects. This result shows that it is quite complicated to use compared to the print worksheet.

The reviewer directed that the application must be developed to collect data from several research locations at once. This development is essential because, at the field, the students not only collect data from one location but also collect in several locations. Indeed, each student usually takes data from more than 3 locations at once. Based on these suggestions, added the "New data entry" button into the application to accommodate users. All data is stored in the database for easy data access. A new practical exercise menu is shown in Figure 8.

The revised product has been applied towards 25 biology students of UIN Sunan Kalijaga to gain students' feedback to improve the developed aplication. Table 3 shows that based on students feedback, the product gained a total score of 61.88. Based on the ideal scoring category, the $\mathrm{X}$ score (61.88) lies in the range of $X>60$ or very good (VG). The ideal percentage is $82.5 \%$ which is catagorized as very good (VG). 


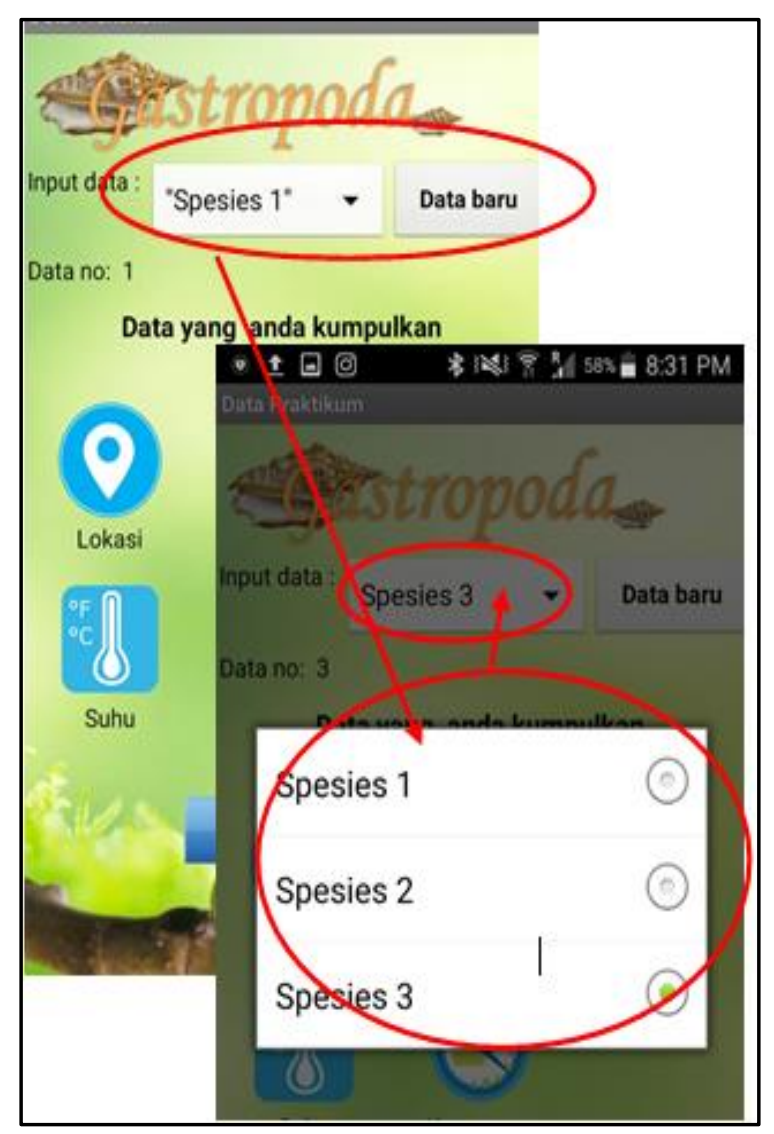

Figure 8. The layout of the practicum menu after getting a revision

Table 3. Product quality

\begin{tabular}{|c|c|c|c|}
\hline No & Aspects & $\begin{array}{c}\text { Percentage } \\
(\%)\end{array}$ & Quality \\
\hline 1 & Media Interest & 84,4 & VG \\
\hline 2 & Material mastery & 76,8 & $\mathrm{G}$ \\
\hline 3 & Display & 86,4 & VG \\
\hline 4 & Accomplishment & 82,4 & VG \\
\hline \multicolumn{2}{|c|}{ Total ideal percentage } & 82,5 & VG \\
\hline
\end{tabular}

The TlOF-based mobile learning is able to force the students' to focus on the instruction, making a more effective and efficient practical exercise activity. This TlOF-based application bears several points in 1) can be ran through smartphone making it more flexible and portable to be operated for field activities. 2) The material can be presented in a more attractive drawings, icons, and panels. 3) The application is complemented by gastropod identification key in order to make the students easier to identify gastropods during the field work. 4) The application can run in offline mode making this application is still running without internet connection.

\section{CONCLUSION}

TlOF-based mobile learning practical exercise is potential to become an alternative of methods in improving practical exercise in teaching ecological concept This Three-Layer Observation Framework-based mobile learning application achieves the quality of "Very Good" with the percentage value of 81.8 according to the experts' validation and the quality of "Very Good" with the percentage of 82.5 in the feed back.

\section{ACKNOWLEDGMENT}

Thanks to the Head of the Department of Biology Education at UIN Sunan Kalijaga for the opportunity during the small pilot test. Thanks also to Postgraduate Studies of Science Education of Universitas Sebelas Maret, Surakarta, at the East Java Province, Indonesia for the opportunity of conducting the research as a part of the master thesis and for the funding.

\section{REFERENCES}

Ajizatunnisa, A., Wahyuni, S., Waluyo, L., \& Miharja, F. J. (2018). Booklet development based on research identification of fiddler crab (Uca spp.) diversity in mangrove ecosystem. JPBI (Jurnal Pendidikan Biologi Indonesia), 4(1), 61-66. https:// doi.org/10.22219/jpbi.v4i1.5337

Arikunto, S. (2013). Prosedur penelitian suatu pendekatan praktik. Jakarta-Indonesia: Rineka cipta.

Branch, R. M. (2009). Instructional design: The ADDIE approach (1st ed.). New York: Springer US. https://doi.org/10.1007/9780-387-09506-6

Bybee, R. (2010). The teaching of science: 21st century perspectives. (C. Reiburg, J. Horak, A. Cooke, J. Cusick, W. Rubin, \& A. America, Eds.) (1st ed.). Arlington, Virginia, US: NSTA Press. Retrieved from https://books.google.co.id/books/about/Th e_Teaching_of_Science.html?id=T416plkl YC4C\&redir_esc $=y$

Chen, Y. S., Kao, T. C., \& Sheu, J. P. (2003). A mobile learning system for scaffolding bird watching learning. Journal of Computer Assisted Learning, 19(3), 347-359. https://doi.org/10.1046/j.0266-4909.2003. 00036. $\mathrm{x}$ 
Crozat, S., Hu, O., \& Trigano, P. (1999). A method for evaluating multimedia learning software. In International Conference on Multimedia Computing and Systems Proceedings (Vol. June, pp. 714-719). IEEE. https://doi.org/10.1109/MMCS.199 9.779287

Hayat, M. S., Anggraeni, S., \& Redjeki, S. (2011). Pembelajaran berbasis praktikum pada konsep invertebrata untuk pengembangan sikap ilmiah siswa. Bioma, l(2), 141-152. https://doi.org/10.26877/ bioma.v1i2,\%20Oktober.352

Huang, Y., Liao, Y., Huang, S., \& Chen, H. (2014). A Jigsaw-based cooperative learning approach to improve learning outcomes for mobile situated learning. Educational Technology \& Society, 17(1), 128-140. https://doi.org/10.2307/jeductec hsoci.17.1.128

Huang, Y. M., Lin, Y. T., \& Cheng, S. C. (2010). Effectiveness of a mobile plant learning system in a science curriculum in Taiwanese elementary education. Сотрuters and Education, 54(1), 47-58. https:// doi.org/10.1016/j.compedu.2009.07.006

Hung, P. H., Hwang, G., Lin, Y., Wu, T., \& Su, I. (2013). Seamless connection between learning and assessment- applying progressive learning tasks in mobile ecology inquiry. Educational Technology and Society, 16(1), 194-205. Retrieved from https://pdfs.semanticscholar.org/03e3 /1499332aed4c21d9ff05a943eabff36aba3a .pdf

Hung, P. H., Lin, Y. F., \& Hwang, G. J. (2010). Formative assessment design for PDA integrated ecology observation. Educational Technology and Society, 13(3), 33-42. Retrieved from https://pdfs.semanticscho lar.org/b571/1c6400a5d8c35befc9ba785a5 77419a8cf46.pdf

Husamah, H. (2015). Blended project based learning: Metacognitive awareness of biology education new students. Journal of Education and Learning, 9(4), 274-281. https://doi.org/10.11591/edulearn.v9.i4.21 21

Isaacs, S. (2012). Turning on mobile learning in Africa and the Middle East (Illustrative Initiatives and Policy Implications No. 1). UNESCO Working Paper Series on Mobile Learning. Paris, France. Retrieved from http://unesdoc.unesco.org/images/0021/00 2163/216359E.pdf
Kirschner, P. A., Sweller, J., \& Clark, R. E. (2006). Race and the criminal justice system: An overview to the complete statistics. Educational Psychologist, 41(2), 75-86. https://doi.org/10.1207/s15326985 ep4102_1

Lewinsohn, T. M., Attayde, J. L., Fonseca, C. R., Ganade, G., Jorge, L. R., Kollmann, J., ... Wolfgang W Weisse. (2014). Ecological literacy and beyond: Problem-based learning for future professionals. Royal Swedish Academy of Sciences, Juni, 1-9. https://doi.org/10.1007/s13280-014-05392

Noviar, D. (2016). Pengembangan ensiklopedi biologi mobile berbasis android materi pokok pteridophyta dalam rangka implementasi Kurikulum 2013. Jurnal Cakrawala Pendidikan, 35(2), 198-207. https://doi.org/10.21831/cp.v15i2.8255

Osuafor, A. M., \& Amaefuna, I. A. (2016). A survey of biology teachers use of activityoriented, laboratory practical exercises to promote functional biology education. Education and Learning (EduLearn), 10(3), 281-290. Retrieved from http:// journal.uad.ac.id/index.php/EduLearn/arti cle/view/3952.

Schaal, S., Matt, M., \& Grübmeyer, S. (2012). Mobile learning and biodiversity bridging the gap between outdoor and inquiry learning in pre-service science teacher education. Procedia - Social and Behavioral Sciences, 46, 2327-2333. https://doi.org/10.1016/j.sbspro.2012.05.4 79

Shipstead, Z., Lindsey, D. R. B., Marshall, R. L., \& Engle, R. W. (2014). The mechanisms of working memory capacity: Primary memory, secondary memory, and attention control. Journal of Memory and Language, 72(1), 116-141. https://doi.org/10.1016/j. jml.2014.01.004

Singh, M. P., \& Jain, M. K. (2014). Evolution of processor architecture in mobile phones. International Journal of Computer App lications, 90(4), 34-39. Retrieved from https://pdfs.semanticscholar.org/7174/575 49f70742352e1116851b39391aa43b0f7.p df

Sung, Y.-T., Chang, K.-E., \& Liu, T.-C. (2015). The effects of integrating mobile devices with teaching and learning on students' learning performance: A meta-analysis and research synthesis. Computers \& Educa 
Sambodo et al. / JPBI (Jurnal Pendidikan Biologi Indonesia) / 4 (3) pp. 225-234

tion, 94, 252-275. https://doi.org/10.1016/ j.compedu.2015.11.008

Tulbure, B. T., \& Siberescu, I. (2013). Cognitive training enhances working memory capacity in healthy adults. A pilot study. Procedia - Social and Behavioral Sciences, 78, 175-179. https://doi.org/10.1158/10780432.CCR-17-3028
Wulandari, A. D., Kurnia, K., \& Sunarya, Y. (2013). Pembelajaran praktikum berbasis inkuiri terbimbing untuk meningkatkan keterampilan berpikir kritis siswa SMA pada materi laju reaksi. Jurnal Riset Dan Praktik Pendidikan Kimia, 1(1), 18-26. https://doi.org/10.1007/s00299-007-03258 